\title{
TEXT AS A RELIGIOUS LANGUAGE CONTROLLER OF MUSLIM SOCIETY: THE BLUEPRINT OF THE CODIFICATION OF HADITH
}

\author{
Rifqi Muhammad Fatkhi \\ Syarif Hidayatullah State Islamic University (UIN) Jakarta \\ rifqimuhammad@uinjkt.ac.id \\ Hilmy Firdausy \\ Syarif Hidayatullah State Islamic University (UIN) Jakarta \\ hilmy.firdaus@uinjkt.ac.id
}

\begin{abstract}
This paper describes the problem of religious reading discourse that leads to puritanism, "romanticism" and "textualism." The text is considered to be a storage memory of the past which, to some extent, has more power than the visual or rational tradition. To examine this thesis, the writer uses the discourse around the codification of hadith as a sample to see the motive of institutionalization of the text. There are two periods which, according to the writer, represent it; codification period of various Islamic knowledge and pre-tadwin that have a major influence on the codification.
\end{abstract}

Keywords: Hadith, Codification, Puritanism.

\section{Introduction}

Arrazy Hasyim reveals that the phenomenon of current puritanization essentially grows from the exclusive tradition of theological understanding that is often triggered by romanticism to the early Islamic generation that is considered as supreme. Also, the textual factor in understanding religious texts also exercises considerable control in the formation of Salafi reasoning. Such an attitude, according to Hasyim, is an agent for all forms of sectarian political conflict and various customs of decline in Islamic thought. (Hasyim, 2017: Thesis)

Al-Jabiri mentions that there are three ideological models that became the epitome of the motion of Islamic thought in the modern age; Salafi-fundamentalism, liberalism, and left-reformism. (al-Jabiri, 1993: 12) All of them, al-Jabiri continued, had a unity of reason called "Salafi." (al-Jabiri, 1993: 12) The Salafi referred to al-Jabiri is an inconsistent system of thinking in mapping out the historicity of the past and its relationship to the present and the future. In effect, the system then undermines the element of historicity and challenges objectivity in all its thinking work. (al-Jabiri, 1993: 16) It is proved by the fact that these three ideological forms are never separated from the two possible dialogues; the reader who pervades the text, or the text that covers the subjectivity of the reader.

Puritanism and Salafi mentioned by Arrazy and al-Jabiri, actually force the problem of "romanticism" and "textualism." The first signifies the way of thinking based on the gloomy memorabilia that is considered noble, the seeding of desires, dreams, the true ambition born of despair. The second is the stage of disclosure and model of struggle that occurs in the ongoing tradition. "Salafi" is not merely a religious model that signifies the authenticity, but when the context of reasoning, the Salafi referred to -as it is meant in this paper- is a historical and non-objective thinking system (al-niz̄ām al-ma 'rifí). Salafi 
logic in addition to operating in puritanical religious models, may also be activated in even the most contextual and liberal religious models. (Firdausy, 2016)

Romanticism and textualism with the all problematic reading above should be admitted as a method of Muslim reading until now. It participates in almost several sectors of Islamic scientific; tafsìr, hadìth, fiqh, ușül al-fiqh and all product of science born from 'codification'. At this point, as far as I show later, the frame of puritanism and romantic -based on fixed in sacrality of text- creep not only on the theological problem but also on the whole sector of Islamic discourses.

The first proper question presented to begin the discussion is when does the text become storage memory of the past than at the certain level it more powerful than another medium such as visual tradition or reason? It gradually becomes a current Muslim religious understanding problem that occur the "religious-basic-text" model. What I mean as "religious-basic-text" is not as mentioned by Shāfi'i"s Madhhab, but a model focused completely on body text; the one and only! This religious model abolishes tradition, and "religious-basic-activities" learned hereditary visually and directly transmitted from one to another; a religious model which is not directly as tafsīr or real imagination related to the content that will be delivered by religious texts.

This paper used the discourse of hadith as the tested sample. For that interest, there are two epistemic contours considered as important things to discuss. First is the codification period as early systematization whole Islamic discourses into independent scientific. Within observation back to assr al-tadwinn, some core problems are found which help us to imagine the intention within the codification of hadith. Second is precodification period should be admitted that it has great influence in the establishment of discourse system which is going on codification century. Through the second element, we can see the motive behind codification and institution of text as the key element in the religious language.

The two discussions at least above will clarify an explanation when "correctness" of Sahih al-Bukhārī and Sahih Muslim, or al-Kutub al-Sittah was produced and standardized? When does that "correctness" become a norm, as if Muslim cannot refer to hadith beside those "two" or "six" books? What is the motivation of the critic of hadith in the centuries after tadwin until it emerges the categorization of work or canonization? The two discussions, automatically, also explain the history of the meeting between text and past romanticism. This paper is submitted as consideration of genealogy for observing discourse frame in the codification century that is a fundamental for all of the Islamic scientific movement especially hadīth and its influence within affirming of the recent religious-text model.

\section{The Internal Problem of $\boldsymbol{A s s r}$ al-Tadwīn as Culmination Discourse}

All codification periods ( $a s ̧ r$ al-tadwin) within the trajectory of civilization movement in the world have the same hole of problem. In Indonesia, the codification requires Javanese script to be standardized and being Latin script. The work had begun since the codification of Java-Latin dictionary in XVIII century. As a result, some santri's writing traditions supporting ancient Javanese lettering onto pronunciation mode of hijaiyyah letter become lose because of "standardization" and "puritanization" of the script. Method of writing hanacaraka for pronouncing "' $a$ " ('ain letter) is changed to "nga", "syari"at" word becomes syarengat. The writing mode was changed because the available of hanacaraka script and more close with pronouncing of " $a$ " letter is "nga" (the 20th in hanacaraka script after $m a, g a, b a$ and $t a$ ). Finally, that writing tradition is considered "suburbs" and deviate and later it be removed because it is not original and damages lettering culture. (Baso, 2016) 
There is an explanation in the philosophy of science about the issue mostly discussed by scholars. The question is when does knowledge become science? The answer is when knowledge is gained trough some process based on logical premises, and it has to be arranged systematically.

There is an explanation in the basic philosophy of science about the period of knowledge becomes a science. (Suriasumantri 2011: 10-12) That is when a knowledge gained through a process based on logical premises, and it is arranged systematically. (Suriasumantri, 2011: 10-11) In the western philosophy as well as Islamic philosophy, both in the philosophy of western science and Islamic philosophy of science, the two processes are the pillars of science to be recognized and expressed its authority. Consequently, when science is trustworthy, knowledge is not authoritative. The process of knowledge to science is a process that occurs in the age of codification. Codification also requires the process of systematization, proceduralization and positivization aimed at normalizing, labeling and standardizing the existing sciences within the sphere of civilization; the stage of development of a civilization from "not advanced" to "advance," from "small" to "big," from "unofficial" to "official" and so on. Such codification work processes will certainly blow out the "minor," "inferior," "unofficial" and "minor" things. The real standardization and standardization is a pretext for the legitimacy of scientific truths for the elite and the dominant science model in progress. Al-Jabiri called it a transition from the age of "ignorance" to the "Islamic" era; the age of Jahiliyyah is symbolized by "chaos," "non-system" and "darkness." While the post-codification era of Islam is symbolized by "regularity," "systematic" and "bright." Due to the darkness, the pre-codification age of ignorance has absolutely no internal epistemological clarity and continuity in the future. (al-Jabiri, 1991: 57) dichotomy;

Al-Jabiri presented an important document to describe the problem of such a

"Al-Dhahabi said: In the year $143 \mathrm{H}$ the Islamic scholars had [started] to "tadwīn" the Hadīth, Fiqh, and Tafsir. Ibn Jurayj in Makkah also authored the book, Malik wrote al-Muwatța' in Medina, al-Auza'ī in Sham, Ibn Abī 'Arūbah, Hammād ibn Salamah and others in Bașra, Ma'mar in Yemen, and Sufyān alThawrī in Kufa. At the same time, Ibn Isḥāq wrote al-Maghāzi, and Abū Hanīfah composed [kitāb] on fiqh and $r a^{\prime} y u$. Shortly after that came Hushaym, al-Layth, and Ibn Luhay'ah, then Ibn al-Mubārak, Abū Yūsuf, and Ibn Wahab. Tadwīn movement in some scientific disciplines is increasingly and multiply widespread. Arabic books, lexicography, and history were published at the time. Before this tadwin, people only rely on memorization and narrated the science of manuscripts that are not arranged." (Al-Suyūṭ̂̄, 1959: 115)

Al-Jabiri adopted this text to verify that aṣr al-tadwin is not only a period when all fields of Islamic scientific are codified. Moreover, it is a stage of representation of the history of Islamic civilization that even determines what should be known about the past pre-codification and what is unfit to know. The Așr al-tadwin for al-Jabiri is the stage of "i 'àdat al-binā' al-thaqāfat al- 'ām" (cultural reconstruction comprehensively). (al-Jabiri, 1991: 70) The Muslim's knowledge of the centuries before codification is determined by the projection of group domination-ideologically and politically-in the codification period itself. Fragmentation of the past was formed and designed in those centuries.

There are several things that reflect the text: first, așr al-tadwin aimed at alDhahabī is the așr al-tadwin started from the 2nd century of Hijrī (the years in the period of Caliphate al-Manșūr al-'Abbasi). This restriction is intended to disintegrate the period with other așr al-tadwīn models, such as tadwin in the time of the Prophet Muhammad Saw., when tadwin was understood in general only limited bookkeeping, restrictions and 
problem-solving. (al-Shahrawarzi, 2014: 37) Therefore, așr al-tadwīn meant al-Dhahabi is not only limited to bookkeeping, restriction and problem-solving, but also the process of reconstruction and representation of the scientific grounds as well as the history of Islamic civilization. (al-Jabiri, 1991: 63)

Second, al-Dhahabi confined codification in only a few areas that are not necessarily Sunni. Mecca, Medina, Bașra, Kufa, and Sham are some dominated areas. (alJabiri, 1991: 63) From this mention and restriction, al-Dhahabi has assigned some minority tadwin in other parts conducted by a small group of subordinated ideas. (Saifudin, 2003: 33-58). Such as the tadwin movement of the Shi'i group pioneered by Ja'far al-Ṣadiq (148 H) and other insignificant groups. (Zamzami, 2013: 24-36).

Third, al-Dhahabi did not forget to give demarcation boundary between pre and post-tadwīn. If the pre-intellectual life of the Muslims is still in shambles because "yatakallamūna min hifdhihim aw yarwauna al- 'ilm min șihaf ghayru murattabah." (alSuyūti, 1959: 115) On the contrary, the debate of Islamic scholarship after tadwīn has been organized, systematized and independently standardized. Here then the labeling of scientific authority gained its relevance to the distinction between pre and post-tadwin scholarship. Which politically also gave birth to authority, "the truth is what is written in the text and written in ink." not the spoken, and the heard. From this also, the classic consensus on oral or rote traditions is changed and twisted into a tradition that is no more stable than the literal tradition.

The quote of al-Dhahab's vow gives a bit of a picture that silencing and exclusion take place in the context of Islamic civilization, including in the history of the discourse of hadith. What has been shown so far is the books that comprehensively represent the growing ideological color and control of the moment, especially in certain areas as aldhahab. In fact, in existing historical data, other groups are no less massive in tadwīn processes, which, again, are adapted and based on their interests as ideological institutions.

Sunni and Shi'a are the two great powers that fought in the third century. Both are ambitious to legalize their respective ideologies by codifying the hadiths in that century. While in the Sunni known al-Kutub al-Sittah as the final form of the long story of Hadith's discourse, it is known in the Shī'ah al-Kutub al-Arba'ah which is the culmination of the hadith discourse they developed in the second and third centuries such as al-Kutub al-Arba'ah aimed in Shi'ah is al-Käfífì 'Ilm al-Dīn by al-Kulaynī (d. $329 \mathrm{H}$ ), Man lā Yahduruhu al-Faqīh by Ibn Babawayh (d. $381 \mathrm{H})$, Tahdhīb al-Ahkām dan alIstibșār by al-Ṭūsī (d. 460 H). ('Ali, 1996: 36; al-Amin, 1406/1986: vol. I, p. 144.) Then the question is, what kind of factors lie behind the implementation tadwīn with such a way of working?

Antonio Gramsci, Gayatri C. Spivak to Radhar P. Dahana believed that the subalterns had no chance to present themselves in history. (Dahana, 2016) History is a representative product of a dominant group or discourse. The canonization of al-Kutub alSittah which has now become an ideology "if you want the authentic hadiths of these six books," (Barthes, 1968) is the history of the discourse of the hadith itself. From these facts, it can be concluded that the most decisive factor in the process of writing of Hadith in the third century, in addition to the internal epistemic problem of the codification project itself, is the ideological factor.

\section{From Idea-Sectarian Politics to The Authority of Disciplinary Discourse}

After the Prophet's death, due to political conflict, the words of the Prophet or even the entire base of religious texts became the weapon of group interest. In this chaos situation, Shi'a and Khawarij are two major groups that constantly seek to build political 
authority and the validity of their position. In addition to these two groups, the so-called "white camp" consisted of "ahl al-'ilm wa al-'ibādah." Some of them are "Abdullāh b. 'Umar, Abū Mūsá al-Ash'arī, Sa‘īd b. Abī Waqqāsh and Ibn Maslamah. (Baso, 2006: 6970) Generally speaking, this a-political group consists of mufassirs and narrators of hadith who try to get out of the great conflict and focus on the development of science and worship. The group inhabits and populates mosques, conducts chanting and nursery values, which indirectly give rise to a "social imagination" (al-Jabiri, 1998: 57) of other options or alternative movements outside of Shī'a and Khawārij.

The social imagination then gained momentum when Hasan al-Bașrī was present and openly embodied the worldview of "ahl al-ilm wa al-'ibadah" as a criticism of Jabriyya-Umayyad ideology. (Dhahabi, 2003: 295-298; al-Ṣalabi, 2008:14; al-Jabiri, 1995: 306-311). From its "white" and "a-political" position, the Ahl al-Sunnah wa alJama 'ah embryo then really becomes the opposition's "party" to the regime that claims that "its power has been embedded in the will of God." From the spark of thought Hasan al-Bașrī, the Mu'tazilites were later born.

Since tahkim the text of the Quran or hadith tends to be a tool of legitimacy that worsens stability and social order since the time of Abū Ja 'far al-Manșūr came to power, "reason" has a special place compared to other representations of thought. Intellect is considered capable of weighing and resolving an integral conflict between politics and religion (state-religion) which almost two centuries into a dark dream of Muslims. Also,

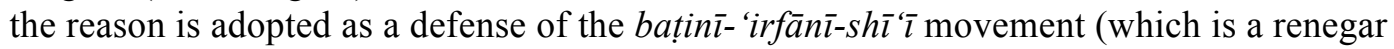
of the Shi'a group), which is known as a rebellious provocateur for all Umayyad and 'Abbasid caliphs.

Ibn al-Muqaffa (Baso, N.y: 94-132) then emerged and became one of the tadwīn architects by beginning to translate the rational Persian political texts to support the "reason" base used by the government. In this period, it is understandable if the Mu'tazila spreading into a role model of Islamic thought, (Baso, N.y: 76) which indirectly also helped remove the group "ahl al-'ilm wa al-'ibädah" back to the periphery; to mosques and madrasas.

Though politically defeated, the Ahl al-Sunnah wa al-Jama' 'ah group won a cultural landscape, especially when the 'Abbasid dynasty held a massive codification project as a further agenda of what Ibn al-Muqaffa had done. Through codification, the group consisting of the narrators of hadīth, the jurists, and the interpreters saw the path to a formation of a new power of "text." One propagandist force is an effective means of influencing the masses and deploying indoctrination. Not just Sunnis, Shī'i groups, and other groups also see this golden opportunity; codification for indoctrination and ideological stability. It is from this context that the books of hadìth, including Sahih alBukhārī, Șah̄ịh Muslim, and Șaḥịh ibn Khuzaymah were born.

The process of integrating philosophy into the discourse of Islamic scholars encourages the batinī- irfäni-shi ' $\bar{l}$ groups to co-opt the philosophy of neo-platonism and hermitian philosophy as a basis for their belief and legitimacy for their imämah-ulühiyyah doctrine. (al-Jabiri, 1997: 17-18). The Mu'tazilites with their 'minds' are no longer able to discipline and fortify the power of the increasingly philosophical criticism of the philosophical bātinis-irfānī. So no wonder then if he was thrown out of his position as the state ideology.

Shortly, in such cases, only the text has the power to discipline those mystical movements that are unbroken. When a religious model emerges that does not have a footing in the "text," it can be directly banned and burned. At this moment, the "text" power of the Ahl al-'ilm wa al-'ibädah people who become incarnated into the Sunni group gets on stage with the adoption of Sunni ideology as the official state ideology. 
Instantly, the text becomes the new means of control and discipline as well as the space for the eternal dreams of the stability of the socio-political order which is about to be rebuilt as it used to be in the time of the Prophet. (Al-Jabiri, 1997: 21).

In the context of several centuries post-codification, Jonathan Brown presents data that the canonization of Șahịh al-Bukhārī and Șahīh Muslim is inseparable from the political interests of the ruler, which is also automatically a very ideological process of standardization. In the opening paragraph of his book introduction, Brown directly shows the data that in the fifth century of the Hijra. Nizam al-Mulk heard the result of a hadith research called Șahịh al-Bukhārī and then made it the ultimate reference and teaching material for cast, judges, scholars, and scientists in general. (Brown, 2007: 3). Of course, this is not without reason, even if the argument is the validity of the hadith that is in it, then we can describe the term "sahinh" to the limit when the community of activism ('amaliyah) said to be valid and justified if there is text.

What Brown presents is one of the facts and historical evidence from the previous brief description of the blue print of the codification project that occurred in the second and third centuries of the hijra. This construction will also explain the birth of the categorization work agenda as the embryo of the canonization project initiated by alMaqdisī and al-Hāzimī. Why for example Șahīḥ Ibn Khuzaymah and Șahịh Ibn Hibbān are not included in the al-kutub al-sittah ranks and are categorized in a group that al'Irāqī calls "al-Ṣahịh al-Zā'id?" The whole can be visible in the frame of discourse that I have described earlier. (Firdausy, 2017: 2).

\section{Conclusion}

Reviewing the contours of the history of the codification period is crucial to look at the existing and inherited context of the discourse in the current religious practice of Muslim. History has its beginnings, and as part of history, what goes on is now all aspects, both in the science and practice of transcendental rituals of Muslims, beginning in the age of codification as a great mirror that recognizes the entire course of Islamic history and represents it in a particular frame. In short, codification produces a picture if we ask "What is Islam?" And want to get the answer.

Codification is also the starting point where the interpretation of the past is produced. "What is ignorance and how is a fragmentation to show the past in its most primordial-barbaric apparently at the same time full of images of glory and gold?" Thus, Islam, since the century of codification has been filled by a sectarian vision which is an internal Islamic-Arabic problem which would be a-historical if applied raw in a religious culture that has different discursive formations and historical pace.

Islamic madhhab texts, thus, have not fulfilled the historical validity and objectivity since it was applied as a religious model an sich which is different from the original purpose it was formed as a system of ideological and political thought. Especially when he participated in the context of the culture that does not have a history-like ArabIslam flow that is colored by the problem of socio-political disintegration and crowded by the ambitious images and memorabilia of the past. The tradition of quoting the hadith and positioning the authority of the hadīth books, in hierarchically, is some of the instruments used by Islamic madhhab of texts to pursue and sort out which is "authentic" Islam, "there is the text" and "true" to Islam "which is not authentic," "there is no text" and "wrong." For as I have already described, the existing books of hadīth are not born in the historical phases of such a construction. 


\section{References}

Ahmad bin Rushd, 1997. Faṣl al-Maqāl fi Taqrīri Mā bayna al-Sharì'ah wa al-Hikmah min al-Ittișāl (Bayrūt: Markaz Dirāsah al-Wiḥdah al-'Arabiyyah).

"Ali, Muhammad, 1996."Collection and Preservation of Hadīth", in P. K. Koya, ed., Hadìth and Sunnah: Ideals and Realities, (Kuala Lumpur: Islamic Book Trust).

al-Amin, al-Sayyid Mụ̣sin. 1986. A'yān al-Sh'̄ a. vol. I (Bayrūt: Dar al-Ma'ārif li alMațbū'āt),

Baso, Ahmad in 7th series, 2016. "Pengajian Studi Poskolonial" at Perum Arya Graha, Tangerang Selatan Ciputat.

-------. 2006. NU Studies: Pergolakan Pemikiran antara Fundamentalisme Islam dan Fundamentalisme Neo-Liberal (Jakarta: Erlangga).

Brown,Jonathan, 2007. The Canonization of al-Bukhari and Muslim: The Formation and Function of the Sunni Hadìth Canon (Leiden-Boston: Brill).

Dahana, Radhar Panca . 2016. "Merampok Bangsa Sendiri”, Kompas.

al-Dhahabi, Shamsuddin Abū 'Abdillāh Muhammad bin Ahmmad bin Uthman bin Qaymaz, 2003. Tārīkh al-Islām wa Wafayāt al-Mashāhir wa al-A 'lām (Bayrūt: Dār al-Gharb al-Islāmī).

Firdausy, Hilmy. 2016. "Ragam Pembacaan Hadis: Memahami Hadis melalui Tatapan Postradisionalisme." RELIGIA, vol. 19, no. 2.

-------. 2017. "Mengenal Șaḩih Ibn Khuzaymah: Sistematika, Metodologi dan Posisinya di Antara Kitab Sahih" dalam Jurnal Ushuluddin, vol. 25, no. 2 (UIN Sultan Syarif Kasim Riau).

Gramsci, Antonio 1971. Selections from the Prison Notebooks, Q. Hoare and C.N. Smith, eds., (London: Lawrence and Wishart).

Hasyim, Arrazy. 2017. Teologi Muslim Puritan, Dissertation at SPs. UIN Syarif Hidayatullah Jakarta (not published).

al-Jabiri, Muhammad 'Abid. 1993. Nahnu wa al-Turāth; Qirā'at Mu'āṣirah fi Turāthina al-Falsafi (Bayrūt: Markaz al-Thaqafi al-'Arabī)

1991. Takwīn al-'Aql al-'Arabī (Bayrūt: Markaz al-Thaqafi al-'Arabī).

1998. Al-'Aql al-Akhlāqī al-'Arabī: Dirāsah Tahliliyah Naqdiyah li Nazm AlQiyam fi al-Thaqāfah al-'Arabiyah (Bayrūt: Markaz Dirāsah al-Wiḥdah al'Arabiyyah).

Saifudin, 2003. "Tadwin Hadis dan Kontribusinya dalam Perkembangan Historiografi Islam" in Jurnal Ushuluddin vol. 12 no. 1, pp. 33-58.

al-Ṣalabi, 'Ali Muḥammad Muḥammad. 2008. Al-Dawlah al-Umawiyyah: 'Awāmil alIzdihār wa Tadā'iyyāt al-Inhìyār, vol. 1 (Bayrūt: Dar al-Ma'rifah li al-Ṭibā'ah wa al-Nashr wa al-Tawz'̄')

al-Shahrawarzi, Ibrahim Amin al-Jaf. 2014. Manāhij al-Muhaddithīn; fi Naqd al-Riwāyah al-Tārīkhiyyah li al-Qurūn al-Hijriyah al-Thalāthah al-Ūla (Dubay: Dār alQalam).

Suriasumantri, Jujun. 2011. Filsafat Ilmu: Sebuah Pengantar Populer (Jakarta: Sinar Harapan).

al-Ṣuyūṭi, Jalaluddin, 1959. Tārīkh al-Khulafä' '(Kairo).

Zamzami, Muhammad Subhan . 2013. "Ideologi dan Politik dalam Proses Awal Kodifikasi Hadis", dalam Religio: Jurnal Studi Agama-Agama, vol. 3, no. 1. pp. 24-36. 